\title{
A PROPOSITO DELL'ACCUSA DI MANICHEISMO FATTA A S. AGOSTINO DA GIULIANO D'ECLANO
}

B a tutti nota la vicenda piuttosto singolare occorsa a S. Agostino riguardo al manicheismo. Dopo aver militato in quella religione con alterna convinzione per circa nove anni, la combatté con accanimento con libri e dibattiti pubblici, una volta ritornato in seno alla Chiesa cattolica, senza riuscire tuttavia ad evitare 11 sospetto di essere rimasto, più o meno consapevolmente, manicheo. Ancora oggi, infatti, da parte di più di uno studioso, anche cattolico, gli viene fatta l'accusa di manicheismo, che per primo gli aveva rivolta 11 vescovo pelagiano Giuliano d'Eclano. Costui, dopo la "Tractoria" di papa Zosimo, capovolgencio $1^{\prime}$ atteggiamento di prudente difesa, tenuto fino allora da Pelagio e Celestio, passo all'attacco degli avversari, accusandoli di traducianesimo e di manicheismo e rivendicando per sé e per 1 suol amici la qualifica di cattolici.

So la prima accusa poteva apparire in qualche modo plausibile, in quanto la trasmissione del peccato ereditario veniva presentata da Agostino, almeno come ipotesi, in collegamento con il traducianesimo spirituale delle anime, assolutamente infondata e calunniosa appariva la seconda accusa.

La conversione di Agostino alla fede cattolica, infatt, ora colncisa proprio con 11 superamento del materialismo e dualismo manicheo tanto metafisico che antropologico. Punti fermi di quella soluzione erano 1 seguenti: $1 /$ il male non è una sostanza o una natura; non ha cioè una vera o propria esistenza, da richiedere una causa efficiente o un atto creativo di Dio; e piuttosto una privatio boni, un defectus a bonitate, dovuto a una causa deficiens, che non può essere che la volontà delle creature stesse; 2/ ogni natura o sostanza, in quanto tale, 
¿ buona, perché partecipe dell'essere o della bontà di Dio; 11 male che puó sorgere in esse, per essere state create ex nihi10, puó corrompere, viziare, ma non annullare la bontà naturale; 3/ ì assurdo, pertanto, immaginare, come facevano 1 Manichei, una natura totalmente cattiva, glacché sarebbe puro non essere ${ }^{1}$.

In particolare, per quanto riguarda la natura umana, essa - stata creata buona da Dio, ma in seguito a un volontario peccato si ̀ corrotta e viziata sia nell'anima che nel corpo, e cosi corrotta si trasmette a tutti gli uomini. Per conseguenza, tanto $i$ mali fisici/malattie e morte/ quanto i mali dell'anima /ignoranza e concupiscenza/, che segnano tristemente la presente condizione dell'uomo, sono defectus poenales, vitia, non attribuibili all'originaria creazione divina, ma pene giustamente meritate dal peccato dell'uomo. Contro 1 Manichei Agostino non aveva insistito sulla trasmissione del peccato da Adamo al discendenti sia perché non era necessario sia perché contro di essi non poteva appellarsi all'autorita della Scrittura, soprattutto quella dell'Antico Testamento. Tuttavia, già nel corso della polemica antimanichea, la soluzione del problema dell'origine del male includeva l'idea della trasmissione ereditaria della colpa, come presupposto necessario della giustizia di tutte le miserie fisiche e morali, di cui soffrono gli uomint, compresi $i$ bambini innocenti ${ }^{2}$.

Ebbene, questa soluzione, qui appena descritta per sommi cap1, con cui Agostino aveva creduto di aver definitivamente superato 11 dualismo manicheo e che giudicava conforme alla rivelazione biblica e alla fede della Chiesa, fu giudicata del tutto insufficiente e inadeguata da Giuliano d'Eclano: "Inter te et Manichaeum $/ \ldots$ / nulla de qualitate naturae, sed de solo est auctore dissensio /.../. Ambo igitur tu et Manichaeus, pariter malum naturale firmatis, id est, ambo naturam malam hominum aeque dicitis, sed ille fidelius, tu fraudulentius" ${ }^{3}$.

1 Cer Contra Iulianum I 8, 37, PL 44, $666 \mathrm{~s}$. ; De natura bon1 $6-10,17$, CSEL 25, 857-859, $861 \mathrm{~s}$.

2 Cer De libero arbitrio III 15, 43, CCL 29, 300 s.; III 18, $51 \mathrm{~s} ., \operatorname{CCL} 29,305 \mathrm{~s}$; ; III 20,56, CCL 29, $307 \mathrm{~s}$.

3 Iulianus Aeclanensis citatus in: Augustinus, Contra secundam Iuliani responsionem imperfectum opus III 154, PL 45, 1309 . 
Secondo l'osservazione di Giuliano, il punto debole della soluzione agostiniana consisterebbe nel patto, che essa sposta il tempo della corruzione della natura umana dal momento della creazione al momento del peccato del primo uomo, credendo cosi di assolvere Dio dall'accusa di ingiustizia, ma conserverebbe il concetto fondamentale del manichelsmo quale è quello di male naturale, perché continua a parlare di peccati innati e di una natura cattiva fin dalla nascita; d'altra parte la soluzione agostiniana non riuscirebbe neppure a liberare Dio dall'accusa di iligiustizia, anzi l'aggraverebbe, perché egli imputa alle persone peccati commessi da altri ${ }^{4}$.

Giuliano, invece, ’̀ dell'avviso, che 11 problema dell'origine del male, che tanto angustia $i$ manichei e Agostino, non si risolve imraginando un inconcepibile e Inammissibile mutamento della natura a causa del pecoato dell'uomo: "Nam credere naturale, quod fatearis de voluntate susceptum, non dico ineruditae, sed ebriae mentis inventum est" 5 . A suo avviso 11 problema dell'origine del male si risolve facilmente operando le debite distinzioni: il vocabolo "male" si applica propriamente alla colpa e solo impropriamente al supplicium ${ }^{6}$. Il male clò̀ solo 11 peccato e il peccato "non è altro che la libera volontà, che si allontana dalla giustizia" ${ }^{7}$. Egli è profondamente convinto che "non si dà alcur peccato naturale o originale, perché questi due vocaboli significano una sola cosa, che 11 peccato non è volontario, mentre la verità esige che 11 peccato non può essere se non volontario" 8 .

Tra la natura /opera di Dio/ e la libera volontà dell'uomo c’è quindi una netta contrapposizione, al punto che l'una esclude l'altra: "Il peccato, opera della libera volontà, non può essere naturale e tutto ciò che è naturale non può essere peccaton". La natura infatti e principio di attività necessaria, per cui "tutto cìo che è naturale è necessario"10. La natura, d'altra

4 CPr Contra Julianum 1, 3, PL 44, 783; VI 9, 24, PL 44, 836. 5 Contra secundam Juliani responsionem III 154, PL 45, 1310.

6 Ibidem V 26, PL 45, 1465.

7 Ibidem IrI 157, PL 45, 1312 .

8 Ibidem V 43, PL 45, 1479 .

9 Ibidem III 160, PL 45, 1313.

10 Ibidem V 46, PL 45, 1482 . 
parte, "’̀ regolata da leggi immutabili" e "non è certamente in potere del libero arbitrio alcuna mutazione delia natura"11; "con 11 peccato non si muta la condizione della natura, ma solo la qualita del merito" della persona ${ }^{12}$.

Come appare evidente da quanto andiano dicendo, l'accusa di manicheismo, rivolta da Giuliano ad Agostino, trova 11 suo fondamento in una diversa soluzione del problema del male, che a sua volta si fonda su differenti nozioni di "male" e di "natura", prima ancora che su diverse interpretazioni scritturistiche.

Ci chiediamo allora in che modo e per quali vie Giuliano giunse a formarsi simili concetti, tanto estranei alla cultura teologica della Chiesa occidentale e latina. Da sempre, possiamo dire, è stato indicato l'Oriente sirlaco e antiocheno come la fonte di ispirazione del pelagianesimo; in particolare, sulla base di antiche testimonianze, si eranto fatti $i$ nomi di Rufino 11 Siro e reodoro di Mopsuestia. In effetti Giuliano stesso, nella polemica con Agostino, si appellava esplicitamente all' autorita di Basilio, Giovanni Crisostofio e Toodoro di Mopsuestia, definiti "disputatores catholica sanitate Pulgentes"13. Ma Pinora, che io sappia, non si era riusciti a dare concretezza a questa generica indicazione, ldentificando opere precise di questi autori, se si eccettua l'omilia "Ad neophitos" di Giovanni Crisostowo citata esplicitamente da Giuliano ${ }^{14}$. La identificazione sicura di almeno una di dette fonti apre nuovi orizzonti per comprendere la polemica del vescovo pelagiano.

E'noto come nel primo libro del "Contra Iulianum" S. Agostino riporti due testi, sufficientemente ampi, tratti da un' opera antimanichea, attribuita a $S$. Basilio e che Giuliano aveva citato a favore delle sue tesi ${ }^{15}$. S. Agostino, sonza mettere in dubbio la paternita basileiana di quei testi, si limitava a darne una spiegazione che non gli fosse sfavorevole. Neppure nei secoli seguenti l'autenticita di quei frammenti fu mai

12 Ibidem I 96, EL 45, 1112.

13 Ibidem III 111, PL 45, 1295.

14 Contra Julianum I 6, 21, PL 44, 654,

15 Ibidem I 5, 16-17, PL 44, 650-651. 
messa in dubbio. Solo in epoca più recente ad opera di otto Bardenhewer, seguito da B. Altaner, l'attribuzione a Basilio fu decleamente esclusa, perché 11 contenuto di quel testi sarebbe in contrasto con 11 pensiero del grande Cappadoce e perché la notizia di una sua opera antimanichea non trova conferma in nessun altro documento antico ${ }^{16}$. Mancava tuttavia una prova decisiva o soprattutto l'identificazione dell' "Adversus Manichaeos", citata da Giuliano.

Siamo finalmente in grado di darne una indicazione preci-

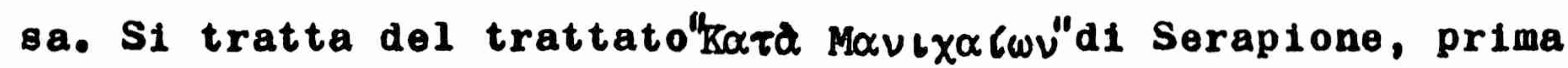
monaco e po1 vescovo di Tmu1s in Egitto, discepolo di Antonio - amico di Atanasio. I due brani, c1tati da Giuliano e riportat1 da Agostino, nella edizione critica, che del trattato suddetto curò R. Plerce Casey nel 1931, occupano gran parte del due capitoletti quarto e quinto ${ }^{17}$. Non sappiamo se la traduzione in latino sia opera dello stesso autore pelagiano o di altri. Certi dettagli, tuttavia, certe aggiunte e certe correzioni Panno pensare proprio a lui.

Questa identificazione getta senza dubbio una nuova luce sulla polemica antiagostiniana di Giuliano e splega in un certo senso la novita e la violenza delle sue accuse. Nel trattato antimanicheo di Serapione, infatti, ritroviamo non solo quello nozioni di "male" e di "natura", che gli permisero di offrire una soluzione alternativa al problema dell'origine del male, ma anche tanti altri spunti e suggerimenti per altri argomenti da opporre al vescovo di Ippona.

Innanzitutto il nuovo/rispetto a quello agostiniano/ concetto di male. Serapione contro i manichei, proprio nel primo Irammento citato da Giuliano, aveva affermato categoricamen-

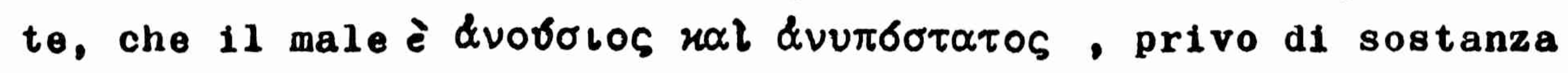

16 Cfr 0. Bardenhewer, Geschjchte der altk1rchlichen Literatur, III, Freiburg i. Br. $1923^{2}, 139$; B. Altaner, Kleine patristische Schriften /TU 83/, Berlin 1967, 273.

17 Serapion of Thmuls, Against the Manichees, by Robert Pierce Casey, Cambridge 1931; ristampato a New York $1969 /=$ Casey/. 


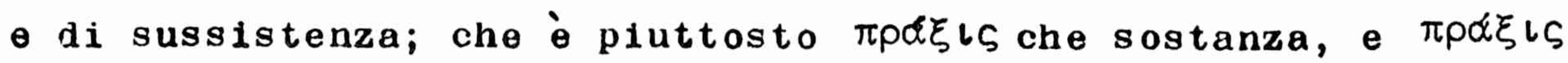
messa in atto dalla volontà ( $\left.\varepsilon_{\mu} \pi \rho \circ \alpha \iota \rho \varepsilon \sigma \varepsilon \omega \varsigma\right)$. Serapione per la veritá parlava anche di volontà malata o di malati nella volonta; la versione latina ha cura di evitare una simile uspressione e preferisce dire "iis qui aegritudinem conversationis de voluntate propria collegerunt", tradendo cosi la mano di un pelagiano. Ma oltre la suddetta nozione generalo di male, come azlone e peccato, Giuliano era interessato a un'altra affermazione fatta da Serapione nello stesso contesto, quando escludeva non solo l'idea di un male sostanziale, ma anche quella di un male che inerisce alla sostanza in maniera da non potersi più separare da essa: "se il male fosse accidentale", argomenta Serapione, "ma fosse ormai inseparabile dalla sostanza, si potrebbe dire che il male non esiste in sé e per sé, ma la sostanza non potrebbe più essere senza male. Se invece 11 male ebbe inizio per accidens dalla volontà, allora puio essere separato da essa con facilita, di modo che il soggetto ritorna puro e non lia più segni di male"18. Sono concetti abbondamente utilizzati da Ǵiuliano, come quando rimprovera Agostino di considerare la concupiscenza una sostanza 19 o quando argomenta che una natura definita cattiva non è suscettibile di salvezza, "quia res mala, et naturaliter mala, nec meretur, nec caperet saluten" 20 .

Anche sul concetto di natura costatiamo una identità di vedute tra Giuliano e Serapione. Anche per il vescovo di Thmuis infatti la natura è immutabile, giacché "cio che ammette variazioni e mutamenti non rientra nella definizione di natura" 21.

A differenza della volontà, che è principio di atti liberi, la natura è principio di attività necessaria. Infatti, argomenta Serapione, "so/gli Apostoli/fossero stati buoni per natura, non avrebbero dovuto mai cadere"22. Ugualmente $i$ corpi, "se fossero cattivi per natura, non potrebbero essere temperanti, se invece fossero cattivi per natura, non potrebbero essere virtuosi"23. D'altra parte, "la differenza di malizia" affermata

18 Serapion ''hmuitanus, Contra Manichaeos 4 , Casey 31.

19 Cer Contra Julianum VI 18, 53, PL 44, 854.

20 Contra secundam Juliani responsionem III 188, PL 45, 1329.

21 Contra Manichaeos 10, Casey 33.

22 Ibidem 15, Casey 35.

23 Ibidein 5, Casey 31 . 
dal Vangelo a proposito del diavoli, "testimonia la differenza di volontà, non di natura", poiché la natura non ammette in sé differenze né il più né il meno: "dove c'è il più e il meno, non c’è più natura, bensi manifestazione di volontà" 24 .

Come si puó costatare, anche da questo breve rafpronto, Giuliano ha in comune con Serapione le nozioni fondamentali della sua polemica antiagostiniana. Ma non è tutto. Una lettura attenta dei due autori ci porta a ritenere che gii elementi in comune siano molti di più; che il vescovo pelagiano abbia attinto dal trattato antimanicneo di Serapione spunti e suggerimenti per altri argomenti antiagostiani. Lo possiamo costatare seguendo 10 schema dei cinque punti, che, secondo la testimonianza di Agostino, costituirebbero la sintesi degli argomenti e delle accuse mossegli contro dal pelagiani e da Giuliano in particolare. Queste pebulae, come ama ironicamente chiamarle, perché servirebbero ai pelagiani a nascondere la loro eresia, sono: la "laus creaturae", la "laus nuptiarum" la "laus liberi arbitrii", la "laus legis" e la "laus sanctorum"25.

1. L a s c r e a $\mathrm{t} r$ a e. Giuliano anzitutto ama presentarsi come il difensore e l'esaltatore dell'opera divina della creazione, in particolare dell'uomo, contro la dottrina agostiniana del peccato originale, che a suo dire equivale a negere a Dio la formazione degli uomini, per attribuirla al diavolo, al pari dei manichei. L'accusa è formulata in due diversi modi: 1/ "Se essi/gli uomini/ nascono colpevoli, non sono creati da Dio, ma dal diavolo, perché nascono dall'uniono del due sessi, voluta e introdotta dal diavolo. Hoc autem sine aliqua ambiguitate Manichaeum est" ${ }^{26} ; 2 /$ secondo 1'altra formulazione, Agostino confesserebbe che Dio è il Creatore degli uomini, ma 11 avrebbe creati per il diavolo, "ut a diabolo legittimo iure teneantur" 27 , come se fosse intervenuto un patto tra Dio e il diavolo, di modo che 11 diavolo può rivendicare per sé tutti coloro che nascono 28 .

24 Ibidem 30, Cas ey 46.

25 Cfr Contra duas epstulas Pelagianorum III 8, 24, PL 44, 606 .

26 Contra Julianum II 32, PL 44, 695.

27 Contra Julianum III 9, 19, PL 44, 712 .

28 Cfr lbidem; cfr anche ibidem III 18, 34, PL 44, 719-720. 
Nel trattato di Serapione ritroviamo le due accuse rivolte ai manichei. Nel cap. $51^{\circ}$ si legge: "Si è spinto/Mani/ Pino alla fabbrica del inondo e questo visibile creato vuole che sia opera del diavolo e che anche l'uomo sia una creazione del diavolo"29. L'altra acusa/che Dio creorebbe gli uomini per 11 diavolo, dopo aver stretto con lui un patto/ trova un riscontro ancora più esplicito, quasi letterale: "Come avviene che cio che era del diavolo diventa di Dio e ció che era di Dio diventa del diavolo, dissolvendo la ramosa inimicizia, anzi stringendo un'amicizia e una alleanza tra Dio, che lascia l'anima al diavolo e il diavolo, che lascia che il corpo serva a Dio?n30 Nel contesto della difesa della creazione si inseriva l'argomento cristologico. Anche su questo punto l'accusa che Giuliano rivolgeva ad Agostino era duplice e alternativa: 1/ se 11 peccato si trasmette a tutti 1 discendenti di Adamo, si da fare di essi un'unica caro peccati", allora anche Cristo, vero uomo, dovette ereditare 11 peccato ${ }^{31} ; 2 /$ se invece Cristo non ebbe nella sua carne la concupiscenza, allora bisogna dire che "non ebbe un corpo della nostra natura", ricadendo cosi nel maniche1smo e nell'apollinarisino 32 .

Un dilemma simile era stato posto da Serapione al manichei: "Se /Cristo/ non è venuto nel corpo, cosa dicono della croce, delle pene dei chiodi e della lancia, del sepolcro o della sepoltura? Se poi, convinti da questi fatti, confessano che 11 Salvatore prese un corpo, come potranno evitare di concludere che anch'egli è stato formato dal diavolo e che non solo 11 corpo umano, ma anche il corpo del Benefattore è opera del diavolo/n 33 Giuliano inoltre sostiene con forza la perfetta umanita di Cristo, la cui carne ebbe tutti i sensi naturali, comprésa quindi la concupiscenza, perché altrimenti non potrebbe essere un perfettó modello di virtu. In questo senso sarebbe inammissibile che egli

29 Contra Manichaeos 51, Casey 72.

30 Ibidem 12, Casey 34.

31 Cfr Contra Julianum V 15, 52, PL 44, 813; Contra secundam Juliani responsionem IV $79 \mathrm{~s} ., \mathrm{PL} 45,1384 \mathrm{~s}$.

32 Cer Contra secundam Juliani responsionem IV 47-53, PL 45, 1365-1370; IV 61, PL 45, 1375; Contra Julianum V 15, 55, PL 44, 814-815.

33 Contra Manichaeos 53, Casey 75 s. 
Posse considerato "nativitate, non virtute felicior"34. In Serapione ritroviamo quasi la stessa espressione a proposito dell'esemplarità degli Apostoli, 1 quali of $\varphi \delta \sigma \varepsilon \iota ~ \nu \iota น \uparrow \sigma \alpha \nu \tau \varepsilon \varsigma, ~ \& \lambda \lambda \lambda^{\prime} \& \rho \varepsilon-$

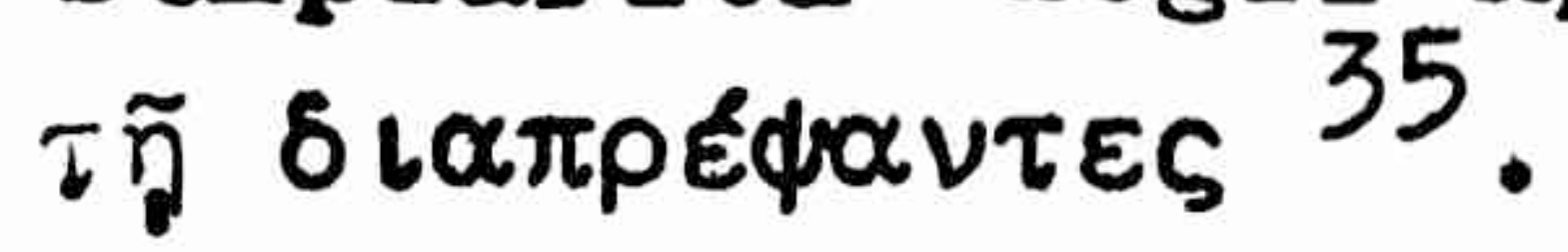

2. La us nupt 1 a $r$ m. Un altro punto, strettamente collegato al precedente e sul quale insiste tanto la polemica di Giuliano è la difesa del matrimonio e la bontà naturale della libido. Non c'è bisogno di ricordare le affermazionl del pelagiano; basta accennare a quelle di Serapione, 11 quale, per la verità, non sempre si esprime positivamente nei riguardi delle passioni. Ció nonostante, oltre a insistere sulla tesi che "Colui che ha fatto l'anima è anche l'autore del

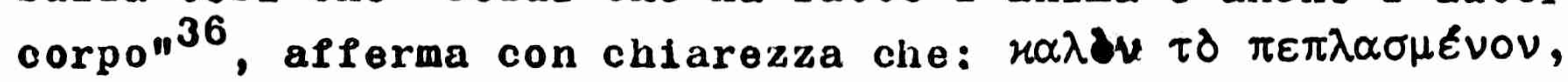
tutto ciò che è creato è buono; in particolare 11 movimento delle membra /e tale è giudicata da Giuliano la concupiscenza/

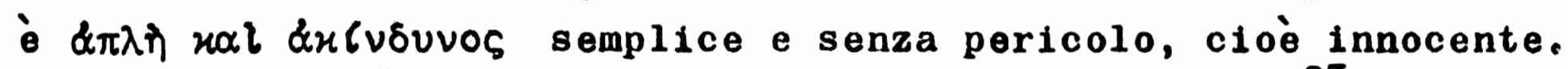
Solo "la qualità dei movimenti risiede nella volontàn". Neppure sul matrimonio parlava esplicitamente. Tuttavia per rivendicare a Dio anche la creazione del corpo, si appellava alle parole di Cristo, che attribuiva a Dio Creatore la formazione dell'uomo e della donna ${ }^{38}$.

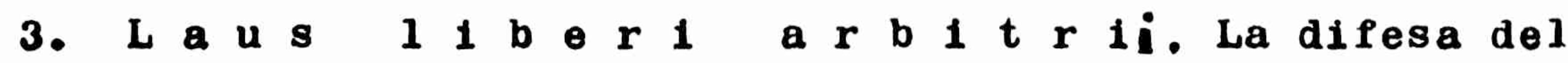
libero arbitrio è un altro cavallo di battaglia della polenica antiagostiniana di Giuliano: la dottrina di Agostino condurrebbe al disimpegno e alla irresponsabilita morale: "Egli offre una scusa agli uomint immorall o malvagi, 1 quali, dopo aver commesso Innominabili turpitudini, possono dire di averle fatte contro la propria volontà o di non aver quindi alcun peccato"39. Anche la Sorittura offre numerose testimonianze, che "mostrano la forza della libertà umana"40, tra le quali citava espressamente Ecclesiastico $/ 15,14 / 41$. La libertà pol consiste nella possibilità

34 Contra secundam Juliani responsionem IV 50, PL 45, 1368.

35 Contra Manichaeos 25, Casey 41.

36 Ibidem 52, Casey 75.

37 Ibidem 18, Casey 37.

38 Cer 1 bidem 52, Casey 74.

39 Contra Julianum V 16, 63, PL 44, 819.

40 Contra secundan Juliani responsi onem I 93, PL 45, 1108.

41 CPr 1 bidem I 45, PL 45, 1066. 
di scelta tra il bene e il male, "expers cogentis necessitatis, quae in suo utpote iure habet" decidersi in un senso o in un altro ${ }^{42}$. Altrove dira che la libertá consiste nel potere della volontà emancipata di scegliere senza alcuna costrizione naturale 43 .

Anche Serapione contro la dottrina manichea del corpo sostanzialmente cattivo, che spinge necessariamente l'uomo al male, aveva esaltato con forza la libertà. Le conversioni degli Apostoli, diceva, "dimostrano che l'animo umano è padrone di sì stes-

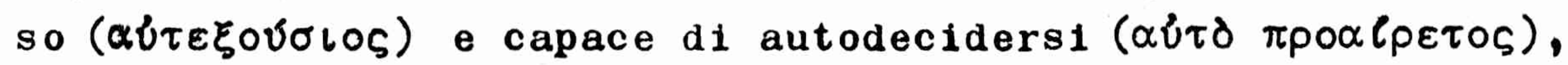

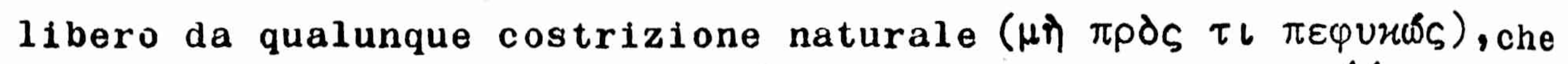
si converte con la sua volontà e si volge dove vuole" ${ }^{44}$. Tra le testimonianze scritturistiche invoca proprio Eccl. 15, 14: "Ed è vero ció che dice La Scrittura: ho posto davanti a te la morte e la vita; scegli ció che vuoi", di modo che, continuava, "chi nell'agire ha fatto una scelta sia chiamato a rendere conto $\theta$ non adduca come scusa la violenza e la necessità degli eventi e neppure si consideri incolpevole, perché nato in tal nodo da non potersi opporre alla natura". E concludendo diceva: "I santi verrebbero incoronati invano e invano verrebbero puniti i malvagi, se la causa /o l'origine/ dell'azione non si puó attribuire a chi agisce" 45 .

4. L a u $\mathrm{s}$ L $\mathrm{g}$ i s. Alla difesa della Legge Antica Serapione giustamente aveva dato un posto di grande rilievo, considerato l'atteggiamento di totale rifiuto dei manichei. Meno comprensibile appare l'insistenza di Giuliano nel farsi difensore ed esaltatore della Legge contro Agostino, che non ha difficolta a accoglierla quale Parola di Dio. Come osservava Agostino, certamente Giuliano "esaltava la Legge per negare la grazia"46, tuttavia non possiamo escludere neppure qui un influsso della sua fonte.

42 Ibidem I 82, PL 45, 1103; cfr anche 1 bidem I 46, PL 45, 1067.

43 Cfr ibidem I 78, PL 45, 1102.

44 Contra Manichaeos 15, Casey 35.

45 Ibidem 9 , Casey 33.

46 Contra duas epistulas Pelagianorum IV 5, 10, PL 44, 616. 
5. L a u s s a n c t o r u m. A motivo della dottrina della persistenza della concupiscenza in tutti gli uomini fino alla fine della vita terrena, confermata con 11 testo di Rom. 7, $14 \mathrm{ss,} \mathrm{riferito} \mathrm{alla} \mathrm{persona} \mathrm{dell'Apostolo,} \mathrm{Giuliano}$ accusava Agostino di "non ritenere gli Apostoli e 1 Profeti pienamente santi, ma solo meno cattivi a confronto di persone peggiori"47. Lui invece sosteneva che "tutti i Profeti e gli Apostoli, ossia i santi dell'Antico e Nuovo Testamento, cui Dio rende testimonianza, furono giusti non solo a confronto dei malvagi, ma anche secondo la regola della virtü"48. Uno spunto per questa polemica Giuliano lo poteva trovare anche nel trattato di Serapione. Costui aveva dichiarato di "non sapere se/i manichei/accusino L'Apostolo e lo annoverino tra gli Apostoli"49, ma aveva insistito non poco nel dimostrare che la conversione degli Apostoli ’̀ una prova che la bontà o la malvagità umana non dipende da'la natura, bensì dalla volontà di ciascuno. Nel corso di questa dimostrazione aveva invitato a contemplare "il coro degli Apostoli", per vedere come "essi che avevano molto peccato, non avevano peccato piü"50 . Sono affermaziont che potevano spingere Giuliano a sostenere le sue tesi e ad accusare Agostino quale "accusator sanctorum et patronus asinorum" 51 .

La identificazione di una delle fonti orientali della polomica antiagostiniana di Giuliano con 11 trattato antimanicheo di Serapione getta una nuova luce sulla polemica del pelagiano. L'influsso è chiaro e innegabile per quanto concerno certe nozioni di fondo della polemica di Giuliano, come: le nozioni di male e di natura, l'opposizione natura-volontà, con l'accentuazione del potere della volontà e l'esaltazione della libertà, quale capacità di autodecidersi, indipendentemente da qualsivoglia costrizione, il rifiuto di assegnare al diavolo un potere

47 Ibidem IV 7,18, PL $44,622$.

48 Ibidem.

49 Contra Manichaeos 14, Casey 35.

50 Ibidem 15, Casey $35 \mathrm{~s}$.

51 Contra secundam Juliani responsionem, IV 56, PL 45, 1372. Questa Prase di Giuliano presenta un analogia singolare con una di Serapione riferita ai manichei: ouviropol $\tau o \tilde{v}$

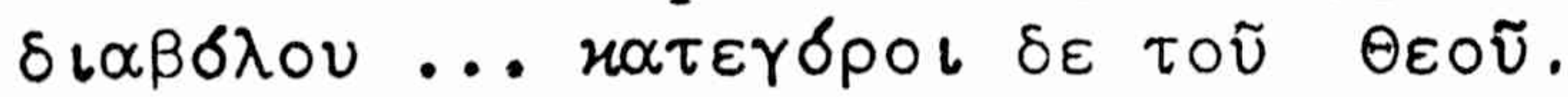


occessivo sul'uomo. Altri spunti o ispirazioni si possono cogliere anche a proposito di altri teni, trattati più o meno estesanente da Serapione e adattati da Giuliano alle posizioni agostiniane, come: la cristologia, il matrimonio, la Legge Antica e la santita dei giusti di entrambi i Testamenti.

Nello Cipriani OSA - Roma

\section{P $\quad r \quad z \quad k \quad k$ a d \\ OSKARZEENIE ST. AUGUSTYNA \\ O MANICHEIZM PRZEZ JULIANA Z EKLANUM}

Znany jest wszystkim zmienny i raczej szczególny stosunek śr. Augustyna do manicheizmu. Po czynnyin praktykowaniu tej religii ze zmiennym przeironaniem przez ok. 9 lat, zwalczał ja później zażarcie, powrócinszy na łono Kościoła Katolickiego poprzez swoje ksiazżi i publiczne dysicusje. Nie udało mu się jednak uniknąc podejrzeń o pozostawanie mniej lub więcej swiadomie manichejczykiem. Nawet jeszcze dziś ze strony niejednego uczonego, nawet katolickiego, pada przeciwko niemu oskarzenie o manicheizm, które po raz pierwszy postawił mu pelagiański biskup Julian z Eklanum. On to po"Epistula tractoria" papieża Zozyma zmieniając postawe roztropnej obrony podtrzymymanej dotiad przez Pelagiusza i Celestiusza, przystapil do atakowania przeciwników, oskarżając ich o traducjontzm i manicheizm, oraz żądając uznania siebie 1 swoich przyjacióz za katolików.

o ile piewsze oskarźenie mogło się w jakiś sposób okazać dopuszczalne - zwazywszy, iż przekazywanie grzechu dziedzicznego było przedstawiane przez Augustyna/przynajmiej jako hipoteza/ w powizzaniu z traducjonizmem duchowym dusz - to drugi zarzut przedstawiał sie jako zupełnie nieuzasadniony i oszczerczy.

Nawrócenie sie $\leqslant w$. Augustyna na wiare katolicka wiazzało się waśnie z przezwycięzeniem materializmu i dualizmu manichejskiego, tak metafizycznego, jak 1 antropologicznego. Mocnyıi punktami tego rozwiązania były następujące założenia: 1/ zło nie jest substancją lub naturąi nie ma zater prawdziwej 1 własnej egzystencji, by wymagać sprawczej przyczyny lub stwórczego aktu Boga. Jest raczej privatio boni, defectus a bonitate, spowodowanym jakąś causa deficiens, którą nie moze być nic innego, jak tylko mola samych stworzeń. 2/ Każda natura lub substancja jako taka jest dobra, poniewaz uczestniczy w bycie 1 dobru Boga; zło, k tóre może wich powstać, bo zostały stworzone ex nihilo, może skazić, lub zepsuć, ale nie zniweczyć dobroci naturalnej. 3/ Absurdew jest więc wyobrazanie sobie, jak to czynili manichejczygy, natury całkowicie złej, poniewaz byłaby ona czystyli niebytem.

Co zaś w szczególności dotyczy natury ludzkiej, to została ona przez Boga stworzona jako dobra, ale w następstwio dobrowolnego grzechu zepsuła sie i skaziła zarówno na duszy, jak $i$ na ciele, $i$ tak jako zepsuta przekazymana jest wszystkim ludziom. W konsekwencji tego zarówno zła fizyczne/choroby 1 śmierć/, jak 1 zła duchowe/niewiedza i pozadliwość/, które smętnie pięt- 
nuja obecny stan człowieka, są defectus poenales, vitia, nie przypisywalne pierwotnemu stworzeniu Bozemu, ale sa karami słusznie ponoszonymi ze względu na grzech człowieka. Występując przeciw manichejczykom Augustyn nie kładł nacisku na przekazywanie grzechu od Adama na potomnych, ponieważ juz to nie było konieczne, juz to dlatego, że przeciw nim nie luógł się odwoływać do autorytetu Pisma św., zwłaszcza Starego Testamentu. Juz jednak podczas polemiki antymanichejskiej rozwiazanie problemu pochodzenie zła zawierało idee dziedzicznego przekazywania winy, jako konieczne założenie służące do usprawiedliwienia wszystkich bied fizycznych i moralnych, dosiegajacych ludzi, nie wyłaczając niewinnych dzieci2.

To jednak rozwi azzanie, opisane tu bardzo ogólnikowo, przez które Augustyn uwazał, że przezwycięzy ostatecznie dualizw manichejski $i$ które uznawał za zgodne z objawieniem biblijnym i wiara Kościoła, przez Juliana z Bklanum zostało uznane za całkowicie niewystarczajace $i$ nieadekwatne. "Inter te et Manichaeum /.../ nulla de qualitate naturae, sed de solo est auctore dissensio /... Ambo igitur tu et Manichaeus pariter malum naturale firmatis, id est, arbo naturam malam hominum aeque dicitis, sed ille pidelius, tu fraudulentius" 3 . Słaby punkt augustyúskiego rozwiazzania polegał zdaniem Juliana na fakcie, że przesuwa ono czas psucia natury ludzkiej od momentu stworzenia do momentu grzechu pierwszego człowieka, uważajac, że w ten sposób uwalnia się Boga od zarzutu o niesprawiedliwośc, ale zachowuje podstawowe pojęcie manicheizmu, jakim jest zło naturalne, poniewaź podtrzynuje mówienie o grzechach wrodzonych 1 o naturze złej od urodzenia; z drugiej strony augustyńskie rozwiazanie nie potrafi uwolnić Boga od zarzutu niesprawiedliwości, owszeu, powiększa go, ponieważ przypisuje on osobom grzechy popeznione przez innych 4 .

Julian natomiast był ziania, że problemu pochodzenia zła, który tak dręczy manichejczyków i Augustyna, nie rozwi ąże się poprzez supozycje niepojetej i niedopuszczalnej zmiany natury $z$ powodu grzechu człowieka, "nam credere naturale quod fatearis de voluntate susceptum, non dico ineruditae, sed ebriae mentis inventum est"15. Problen pochodzenia zła, jego zdaniem, rozwiązuje sie łatwo, poprzez przyjęcie należytych rozróżnień: słowo "zło" aplikuje sie rłaściwie do winy, a tylko niewłaściwie do supplicium. 'Zło miallowicie jest tylko grzechem, grzech zaś "nie jest czymś innym jak wolną wola, która się oddala od sprawiedliwości"7. Jest głęboko przekonany, że "nie ma jakiegoś grzechu naturalnego lub pierworolnego, poniewaź te dwa słowa oznaczają tę saniz rzecz, że grzech nie jest dobrowolny, tymczasem prawda wymaga, ze grzech nie moze być, jak tyliko dobrowolny 18 .

Między natura/dziełem Bożym/a wolną wola człowieka jest więc wyraźna kontrapozycja i to do tego stopnia, że jedna wyklucza druga: "Grzech, dzieło wolnej woli, nie może być naturalny, a wszystko to, co jest naturalne, nie może być grzechem" ${ }^{9}$. Natura bowien jest principium koniecznej aktywności, dla której "to wszystko, co jest naturalne, jest konieczne"10. Natura z drugiej strony "jest regulowana przez niezmienne prawa" a "w nocy wolnej woli nie ma na pewno zadnej zmiany natury"11, "grzechem bowien nie zinienia się stanu natury, ale tylko jakość zastugi" os oby 12 .

Wydaje się więc oczywiste, że posądzenie o manicheizm, skierowane przeciw sugustynowi przez Juliana, znajduje swá podstawę głównie w różnyı rozwiazzaniu problemu zła, które opiera 
się znów na różnych pojęciach "zła" 1 "natury", niż na różnych interpretacjach biblijnych.

Pytany więc, w jaki sposób i jakimi drogami doszedł Julian do uformowania podobnych pojęć, tak obcych teologicznej kulturze łacińskiego i zachodniego Kościoła. Można powiedzieć, że zawsze wskazywano tu syryjski $i$ antiocheński Wschód jako źródło inspiracji pelagianizmu; w oparciu o starożytne śwladectwa wyinieniano szczególnie imiona Rufina Syryjczyka 1 Teodora z Mopsuesti1. Sam Julian wolemice z Augustynem odwoływał się faktycznie wprost do autorytetu Bazylego, Jana Chryzostoma i Teodora z Mopsuestii nazywaj ac ich "disputatores catholica sanitate fulgentes"13. Dotąd jednak, o ile wiem, nie zdołano ukonkretyzować iej ogólnej wskazówki, ze wskazaniem na konkretne dzieła tych autorow, z wyjatkien "Homilii do neoiltów" św. Jana Chryzostoma, cytowanej wyraźnie przez Juliana14. Pewna identyfikacja przynajmniej jednego ze wspomnianych źródeł otwiera nowe horyzonty do zrozumienia polemiki pelagiańskiego biskupa. Wiadomo, że w I księdze "Contra Julianum" Augustyn przytacza dwa dosyć obszerne teksty, zaczerpnięte z jakiegoś antymanichejskiego dzieła przypisywanego św. Bazylemu, a które Julian cytowat na poparcie swoich tez ${ }^{15}$. Sw. Augustyn bez poddawania w watpliwość pochodzenia tych tekstów od Bazylego, ograniczyl się do podania takiego ich wyjaśnienia, które mu odpowiadał o. Także w późniejszych wiekach nie powątpiewano nigdy w autentyczność tych fragmentów. Dopiero w ostatnim czasie dzięki 0. Bardenhewerowi i 1dącym za nim B. Altanerowi, odmówiono zdecydowanie przypisywania ich Bazylemu, poniewaź treść tych fragmentów sprzeciwia się myśli Wielkiego Kapadocczyka, a uwaga o jakimś jego antymanichejskim dziele nie znalazła potwierdzenia w zadnym innym dokumencie starozytnym16. Brakowało jednak decydującego dowodu, a zwłaszcza identyfikacji cytowanego przez Juliana "Adversus Manichaeos".

Obecnie jesteśmy w stanie wskazać ich dokładna identyfi-

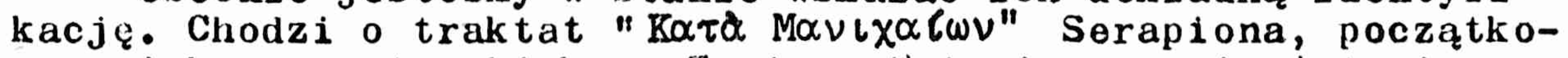
wo mnicha, a potem biskupa Tmuis Eigipie, ucznia Antoniego i przyjaciela Atanazego. Dwa cytowane przez Juliana fragmenty, które przytacza Augustyn, zajmują duża część dwóch rozdzialików /czwartego i piątego/ w krytycznym wydaniu $k$. Pierce Caseya z 1931 roku17. Nie wiemy, czy tłumaczenie na łacine jest dziełem samego pelagiańskiego autora, czy też innych. Pewne jednak detale, dodatki i poprawki pozwalaja myśleć właśnie o nim. Identyfikacja ta rzuca niewatpliwie nowe światło na antyaugustyńska polemike Juliana i wyjaśnia w pewnym sensie nowośc i gwałtownośc jego oskarżeń. W antymanichejskim traktacie Serapiona odnajdujemy bowiem nie tylko pojęcia "zła" i "natury", które mu pozwoliły dać pewne alternatywne rozwiązanie dotyczące problewu pochodzenia zła, ale także inne okazje i sugestie do argumentów przeciw biskupowi Hippony.

Przede wszystkim nowe /w porównaniu z augustyńskim/ pojecie zła. Właśnie w pierwszym fragmencie cytowanym przez Juliana, Serapion twierdzit kategorycznie przeciw manichejczykom,

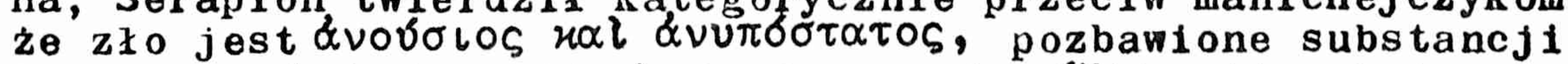

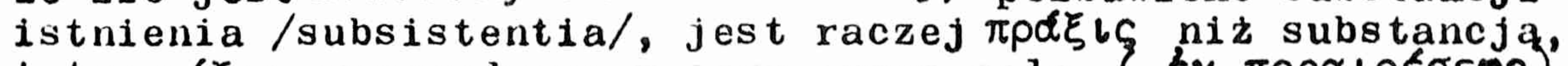

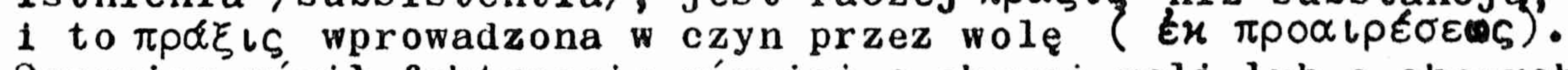
Serapion nówił faktycznie również o chorej woli lub o chorych w woli; przekład laciński stara się unikać podobnych wyrazeń $i$ woli mówić "iis qui aegritudinem conversationis de voluntate propria collegerunt", zdradzając przez to rege pelagianina. obok jednak powyższego ogólnego pojęcia zła, rozumianego jako 
czyn 1 grzech, Julian by zainteresowany innym stwierdzeniem Serapiana dokonanym $w$ tym sanym kontekście, kiedy wykluczał nie tylko ideę zła substancjalnego, ale także zła, które tkwi w substancji w sposób od niej nierozdzielny: "jeśli zło byłoby przypadłościowe", argumentuje Serapion, "ale byłoby nieoddzielne od substancji, to można by powiedziec, że zło nie istnieje in se $i$ per se, ale substancja nie nogłaby dalej istniec bez zła. Jeśli natomiast zło miało początek per accidens ze strony woli, to moze byc od niej łatwo oddzielone podmiot wraca czysty nie mając już znaków złall18. Są to pojecia wykorzystywane obficie przez Juliana; np. ganiac Augustyna za uważanie pożądliwości za substancje ${ }^{19}$, lub argumentując, ze natura określona jako zła nie dopuszcza zbawienia, "quia res mala, et naturaliter mala, nec meretur nec caperet salutem"20.

Także odnośnie do pojęcia natury stwierdzany identyczność poglądów między Julianem i Serapionen. Również dla bpa Tmuis natura pozostaje bowiem niezmienna, poniewaź "to, co dopuszcza wariacje i zmiany, nie pasuje do definicji naturym21. W odróźnieniu od woli, która jest principium wolnych aktów, natura jest principium działalnosci koniecznej. Serapion bowiem argumentuje: "jeśli /apostgłowie/ byliby dobrzy z natury, to nie powinni nigdy upadać"22. Podobnie ciała, "jeśli byłyby złe z natury, nie mogłyby być wstrzemieźliwe i nie mogłyby być umlarkowang, jeśli zaś byłyby złe z natury, nie mogłyby być cnotline"23. Z drugiej strony, "roznorodnośc zła" stwierdzana przez Ewangelię odnośnie do diabłów "poświadcza różnicę woli a nie natury", ponieważ natura nie dopuszcza wobie rózic ani więsszości, ani mniejszości, "gdzie jest więcej lub mniej, nie ma juz natury, owszem jest to objaw woli"24.

Jak moźna twierdzić / nawet na podstawie tego krótkiego porównania/, Julian ma wspólne z Serapionem podstawowe pojęcia polemiki antyaugustyńskiej. To jednak nie wyszystko. Uwaźna lektura tych dwóch autorów pozwala stwierdzić, że wspólnych elementów jest o wiele więcej: że bp pelagiański zaczerpnąz $z$ antymanichejskiego traktatu Serapiona myśli i sugestie takze dla innych argumentów antyaugustyńskich.

Możemy to zauważyć śledząc schemat pięciu punktów, które wg swiadectwa Augustyna miałyby stanowić synteze argumentów i oskarżeń stawianych mu przez pelagian, a w szczególności przez Juliana. Tymi chmurami, jak je ironicznie lubi nazywać, poniewaź miały służyć pelaglanom do ukrycia ich herezji, saz: laus creaturae, laus nuptiarum, laus liberi arbitrii, laus legis 1 laus sanctorum 25 .

1. L a u s c $r$ a $t$ u $r$ a e. Julian lubi przede wszystkim przedstawiać się jako obrońca i chwaloa Bożego dzieła stworzenia, w szczegó Iności człowieka, przeciwko augustý́skiej nauce o grzechu pierworodnym, która jego zdaniem znaczy tyle, co odmawianie Bogu formowania ludzi, a przypisywanie jej diabłu, podobnie jak u manichejczyków. Oskarżenie jest formułowane dwojako: a/ "jeśli oni/ludzie/ rodzą się jako winni, to nie sa stworzeni przez Boga, ale przez diabła, poniewaź rodza się ze zjednoczenia dwóch płci, chcianego i wprowadzonego przez diabła. "Hoc autem sine aliqua ambiguitate Manichaeum est"26. b/ Wedle drugiego sformułowania Augustyn mialby wyznawać, że Bóg jest stwórca ludzi, ale ich stworzył dla diabła, "ut a diabolo legittimo lure teneantur" 27 , jakby zaistniała umowa między Bogiem a diabłem, w taki sposób, iż "diabeł może żądać dla siebie tych 
wszystkich, istórzy się rodzą"28.

if traktacie Serapiona odnajdujemy dwa oskarzinia pod adresem manichejczyków. W 51 rozdziale czytamy: "/Manes/ dotarl az do utworzenia świata, i chce, aby ton stworzony jako widzialny by d liełem diabła 1 zeby takzo człowiek był stworzeniem diabıa"29. Drugie osíarżenie/że Bóg stworzył ludzi dla diabła, po zawarciu z nim umowy/ znajduje jeszcze wyraźniejszy odpowiednik, prawie dosłowny: "Jak to się dzieje, że to, co było diabła, przekształca sie w Boże, a to, co było Boze, staje sie diabła, rozwiązując słynną nieprzyjaźn, owszem, zawiązując przyjaźn í przymierze mięuzy Bogien, który pozostawia duszę diabłu, a diabłem, który pozwala, aby ciało służło Bogul30. W kontekście bronienia stworzenia pojawił sie argunent chrystologiczny. Takze w tym punkcie oskarżenie, które Julian stawiał Augustynowi, było podwojne i alternatywne: a/ jeśli grzech przekazywany jest wszystkim potolikom Adama, do tego stopnia, ze czyni z nich "unica caro peccati", to takze 1 Chrystus, prawdziwy człowiek, winien dziedziczyć grzech"li; b/jeśli natomiast Chrystus nie mial w swoim ciele pożądliwości, to wówczas trzeba powiedzieć, ze "nie miał ciała naszej natury", popadajac w ten sposób w manicheizm i apolinaryzm32.

Podobny dylemat postawiz Serapion manichejczykom: MJesl1 /Chrystus/ nie przyszedz w ciele, to co mówiz o krzyż, o męce gwozdzi i włóczni, o grobie i po grzebaniu? Jeśli zaś, przekonani przez te rakty, wyznaja, ze Zbawiciel przyjaz ciało", to jak będa mogli uniknić wniosku, ze "także i on został uformowany przez diabta, $i$ że nie tylko cjgło ludzkie, alo takze i ciało Dobroczý́cy jest dziełem diabła"l3. Julian ponadto nocno podtrzymuje dosisonale człowieczeństwo Chrystusa, którego ciało posiadało wszystkie naturalne zrilsły, a więc łącznie z pożąd11wościá, poniewaź inaczej nie mogłyby być doskonałym modelem cnót. W tyan serisie byłoby niedopuszczalne, żeby on był uwazany za "nativitate, non virtute felicior"34. Prawie to samo wyrazenie spotykany u Serapiona odnośnie do przykładu apostołów, którzy oủ

\section{L a $u$ s $n u$ p $t$ a $r u m$. Innym punktem zwizzanym} ściśle z poyrzednim, na któryn opiera sié mocno polemika Juliana, jest obrona liałzeństwa i naturalnej dobroci libido. Nie ma tu potrzeby przypominania twierdzeń pelagianina. Wystarczy nawiazać do Serapiona, który faktycznie nie zawsze wyraż sie pozytywnie odnośnie do passiones. Mimo to jednak obok podkresiania tezy, że "Ten, który uczynił duszę, jest takze sprawcáciała"36, twierdzi jasno, ze ${ }^{\alpha} \lambda \partial v$ $\tau \delta \pi \varepsilon \pi \lambda \alpha \sigma \mu \varepsilon v o v-$ to, co jest stworzone, jest dobre; w szczegolności ruch członków/a za taki jest uzna-

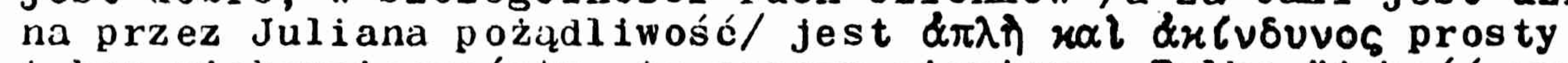
i bez niebezpieczeństw, to zaçy niewinny. Tylko "jakośc ruchów ma swe siediisko w woli"37. Fówniez o małzeństwie nie mówił wyraźnie. Mimo wszystko jednak, aby przypisać Bogu takze stworzenie ciata, powoływał sie na słowa Chrystusa, który Bogu Stwórcy przypisywat uforiowanie mezczyzny 1 kobiety 38 .

\section{L a $u s \quad l 1$ b e r 1 a $r$ b 1 r 1 . Obrona wolnej} woli jest innym popisowym numerem antyaugustyńsiciej polemiki Juliana: nauka Augustyna prowadziłaby do beztroski i nieodpowiedzialności noralnej: "Proponuje on uniewinnienie ludziom niemoralnym 1 złym, któray nawet po popełnieniu nievyrazalnych nikczemności moga powiedzieć, ze popełnili jegwbrew 1ch własnej wol1, a więc, że nie maja żadnego grzechu"l39. Takze Pismo świete dostarcza wielu świadectw, które "ukazuja siłe wolności ludz- 
kiej"40, wśród których cytował wyraźnie Syracha $/ 15,14 /^{41}$. Wolnośc polega także na możliwości wyboru między dobrem a złem, "expers cogentis necessitatis, quae in suo utpote iure habet", opowiadaniu sie za pójściem w jednym lub drugin kierunku42. Gdzie indziej powie,ze wolnośé polega na możności wyzwolonej woli wyblerania bez zadnego natural nego przymusu"43.

Także Serapion wbrew nauce manicilejskiej o ciele substancjalnie złym, które popycha człowieka z konieczności do zła, mocno podkreślał wolność. Nawrócenia apostołów, mówił, "ukazuja, ze duch ludzki jest gospodarzem samego siebie (

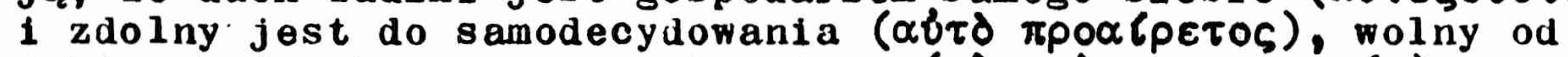

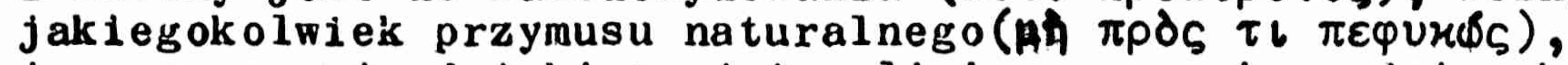
ze nawraca się dzięki swojej woli i zwraca się, gdzie chce" 44 . Ze swiadectw biblijnych przytacza właśnie Syracha /15, 14/: "prawdziwym jest to, co mówi Pismo: położyłem przed tobą śmierć i życie; wybieraj, co chcesz", w taki sposób, iż - mówił dalej -: "ten, kto dokonal wyboru, niech będzie wezwany do odpowiedzialności, a niech nie podaje jako wymówkę gwałtowność 1 konieczność wydarzeń i tym bardziej niech sie nie uwaza za niewinnego, twierdząc, iź taki sposób się urodził, że jest rzeczá niemożliwą przeciwstawić sie naturze". Podsumowując, mówił: "Swięci byliby niepotrzebnie koronowani i daremnie karani przewrotni, jeśli przyczyny/lub pochodzenia/ działania nie moźna przypisać działaj ąc emu" 45 .

4. L a $u$ s L e g 1 s. Słusznie Serapion nadał wielkie znaczenie obronie Starego Prawa, zważywsy na zabiegi zmierzajace ku całkowitemu obaleniu manichejczyków. Mniej zrozumiały okazuje się upór Juliana przejawiajacy się w czynieniu z siebie obrońcy i piewcy Prawa przeciwko Augustynowi, który nie mial trudności przyjąć je jako słowo Boze. Jak zauważyz Augustyn, Julian z pewnościa "wywyżsaz Prawo, aby negować łaskę"46, niemniej jednak nie mozemy nawet i tu wykluczyć pewnego wpływu jego źródła.

5. L a $u$ s $s$ a $n$ c $t$ o $r$ u m. $z$ powodu nauki o pozostawaniu poządliwości we wszystkich ludziach aż do korica ich zienskiego życia, potwierdzonej tekstem $\mathrm{Rz} 7,14$ n., odniesionym do osoby Apostoła, Julian oskarzał Augustyna o "nieuważanie Apostołów i Proroków za w pełni świ ętych, ale tylko za mniej złych porównaniu $z$ os obaini gorszyil"47. On natomiast uważał, ze "wszyscy Prorocy 1 Apostołowie, to znaczy świ eci Starego 1 Nowego Testamentu, o których Bóg daje świadectwo, byli sprawiedliwi nie tylko porównaniu ze złymi, ale takźe pod względein cnoty"48. Równiéz do tej polemiki mógł Julian znaleźć przesłanke traktacie Serapiona, który deklarował, że "nie wie, czy /manichejczycy/ oskarzaja Apostoła i wymieniają go wśród Apostołów"49, ale w dowodzeniu nalega wierokrotnie, że nawrócenie Apostołów jest dowodem, iz dobroć czy złość ludzka nie zależy od natury, ale od woli kazdego. Podczas takiego dowodzenia zachęcał do kontemplowania "chóru Apostołów", aby zobaczýs, jak ci, którzy mieli wiele grzechów, więcej nie grzeszyli"50? Są. to twierdzenia, które mogły pobudzić Juliana do podtrzymyania swoich tez 1 oskarżania Augustyna jako "accusator sanctorum et patronus asinorum"51.

Identyfikacja jednego ze wschodnich źródeł antyaugustyískiej polemiki. Juliana $z$ antymanichejskim traktatem Serapiona, rzuca nowe światło na polemike pelagianina. Wpływ jest jasny 
I niezaprzeczalny, jeśli chodzi o pewne zasadnicze pojęcia polemiki Juliana jak: pojęcie zła i natury, opozycja natura-wola, $z$ akcentowaniew władzy woli $i$ wychwalanien wolności jako zdolności do samodecydowania, niezależnie od jakiegokolwiek przymusu, odrzucenie przypisywania diabłu przesadnej władzy nad człowiekiem. Inne okazje lub inspiracje można znaleźć równiez odnośnie do innych tematów, poruszanych mniej lub więcej szeroko przez Serapiona a wykorzystanych przez Juliana przeciw tezom augustyáskim, jak: chrystologia, małżústwo, stare Prawo 1 świętość sprawiedliwych obu Testamentów.

Tłum. Ks.Stanisław Longosz 0.Bazyl1 Degórsk1 OSPPE 